\title{
THE ADDITION OF BLUE PEA FLOWER (Clitoria ternatea L.) EXTRACT INCREASE ANTIOXIDANT ACTIVITY IN YOGURT FROM VARIOUS TYPES OF MILK
}

\author{
Adi Sutakwa*, Lana Santika Nadia, and Suharman \\ Department of Agricultural Product Technology, Faculty of Agriculture, Universitas PGRI Yogyakarta, Yogyakarta, Indonesia \\ Doi: 10.37195/jac.v3i1.123
}

*CORRESPONDING

Phone: +62-821-3464-2080

E-mail: sutakwa@upy.ac.id

\section{SUBMISSION TRACK}

Recieved: Jan 30, 2021

Final Revision: Mar 24, 2021

Accepted: Apr 14, 2021

\section{KEYWORDS}

Antioxidant activity, Blue pea flower extract, Color intensity, Milk, Yogurt

\begin{abstract}
Blue pea flower (Clitoria ternatea L.) is known as the source of anthocyanin and has potential as a natural blue dye. The present study aimed to determine the effect of additional blue pea flower (BPFE) to yogurt from various types of milk. The study used dried blue pea flowers, extracted with water in 3:1 (g. $\left.\mathrm{L}^{-1}\right)$ ratio, at the extraction condition of $60{ }^{\circ} \mathrm{C}$ and 45 minutes. The fermentation was processed by adding BPFE to (A) liquid skim milk, (B) ultra-high temperature (UHT) milk, (C) pasteurized milk, (D) UHT milk with skim powder, and (E) pasteurized milk with skim powder. Then, the yogurt starter was added to all milk samples, evenly mixed, and incubated for 24 hours at $37{ }^{\circ} \mathrm{C}$. The fermentation of all five different milk to make plain yogurt also processed with same method without addition of BPFE. The antioxidant activity and color intensity of yogurt are evaluated to investigate the effect of BPFE in yogurt. The result showed that the plain yogurt without the addition of BPFE has antioxidant activity and increases with the addition of BPFE. Skim milk BPFE yogurt has the highest antioxidant activity (437.04 ppm) with the values of $\mathrm{L}^{*}, \mathrm{a}^{*}, \mathrm{~b}^{*}$ was $37.35 ; 2.02 ;-1.32$, respectively. Antioxidant activity of the other BPFE yogurt, which was added with skim milk, also increased. The BPFE yogurt made from skim milk or added skim milk had higher antioxidant activity than the other types of milk.
\end{abstract}

\section{INTRODUCTION}

Yogurt is very popular fermented milk products using lactic acid bacteria (LAB), which has been industrialized since 1919 (Aryana \& Olson, 2017). During the fermentation process, LAB produces lactic acid through lactose fermentation, decreases the $\mathrm{pH}$, and produces various both volatile and non-volatile compounds, to exopolysaccharides that affect the quality and the texture of yogurt (Nagaoka, 2018). Yogurt is produced with a complex process of milk transformation. The presence of flavor of yogurt is influenced by several factors, such as starter cultures, source of milk, and the additives used (Chen et al., 2017).

The most common types of microbes used in the production of yogurt are Lactobacillus delbrueckii ssp. bulgaricus and Lactobacillus salivarius ssp. thermophilus (Yildiz \& Bakirci, 2019). In the fermentation process, these two microorganisms can grow individually in milk. When used as a mixed culture, these two bacteria are symbiotic interaction called protocooperation, where L. bulgaricus is reported to produce amino acids and short peptides which stimulate the growth of $S$. thermophilus. At the same time, S. thermophilus produces formic acid, which supports the growth of $L$. bulgaricus (Sieuwerts, de Bok, Hugenholtz, \& van Hylckama Vlieg, 2008).

Yogurt is known as a source of probiotics. The primary role of probiotics, in general, is to optimize digestion metabolism through the repair mechanism of microbiota populations in the digestive tract. At least 15 types of health 
problems that are generally studied have proven the health effects of probiotics (McFarland, 2015). Over time, yogurt product innovation has evolved, producing a variety of yogurt products. Various changes and product differentiations continue to be made to add value to the health of yogurt, one of which is by adding blue pea flower extracts (Singh et al., 2017; Ezzudin \& Rabeta, 2018; Anuyahong, Chusak, \& Adisakwattana, 2020).

Blue pea flower (Clitoria ternatea L.) is known as the source of anthocyanin, and it has potential as a natural blue colorant that grows wild in Asia region (Zakaria, Okello, Howes, Birch-Machin, \& Bowman, 2018; Rashid et al., 2020), including Indonesia. Besides, previous studies result that the extract of anthocyanin from blue pea flowers is more stable. The main compound in the form of delphinidin glucoside (Escher, Wen, Zhang, Rosso, \& Granato, 2020b; Azima, Noriham, \& Manshoor, 2017; Pham et al., 2020). The anthocyanin mixture that is responsible for the blue color of the blue bean flower is delphinidin glycosides (Chu, Wilkin, \& Lemos, 2016).

Food and beverage sometimes do suddenly change the color of there, as a result of changing consumer preferences/interests (Spence, 2019). Anthocyanins contained in blue pea flowers also have the potential to become natural dyes in food. However, the color of anthocyanin is strongly influenced by $\mathrm{pH}$; changes in $\mathrm{pH}$ will change the color of the blue pea flower (Lakshan, Jayanath, Abeysekera, \& Abeysekera, 2019). At neutral $\mathrm{pH}$, the color is blue, and the lower $\mathrm{pH}$ is purple. Anthocyanins in blue pea flowers have been used in beverage, bread, rice, and other products (Pasukamonset et al., 2018; Anuyahong et al., 2020; Rashid et al., 2020). It also can be used as an antimicrobial compound for food spoilage (Chusak, Thilavech, Henry, \& Adisakwattana, 2018; Zingare, Zingare, Dubey, \& Ansari, 2013; Dhanasekaran et al., 2019). From the description, this study aims to find out the effect of addition BPFE to various type of milk on the antioxidant activity and color intensity of yogurt.

\section{MATERIALS}

Blue pea flower powder purchased from Hasil Bumiku, Yogyakarta, Indonesia. The
Lactobacillus bulgaricus (LB) and Streptococcus thermophilus (ST) strains were obtained from the Faculty of Agricultural Technology, Universitas Gadjah Mada, Indonesia. All processed milk and skim powder materials were purchase from local supermarket. The chemicals purchased from Chem-Mix Pratama, Indonesia, including BHT (butylated hydroxytoluene), DPPH (2,2-diphenyl-1picrylhidrazyl), methanol, and aquadest, all in analytical grade.

\section{Blue Pea Flower Extract}

Powdered blue pea flower were extracted into water using waterbath with the ratio ofpowder and water was 3:1 (g. $\left.\mathrm{L}^{-1}\right)$, the temperature of $60^{\circ} \mathrm{C}$, and time of 45 minutes according to the method of Lakshan et al., (2019). Extracts were filtered with a filter paper before added to the milk for BPFE yogurt production.

\section{Yogurt Fermentation}

The study was designed with five different treatments ingredients, namely liquid skim milk, pasteurized milk, pasteurized milk added by skim powder, UHT milk, and UHT milk added by skim powder. The addition of BPFE to all milk samples was carried out before the fermentation process. The amount of BPFE added to milk was $10 \%(\mathrm{v} / \mathrm{v})$ of the milk volume.

The primary starter obtained from Universitas Gadjah Mada was grown in MRS (de Man, Ragosa, Sharpe) media at $37^{\circ} \mathrm{C}$ for 24 hours before used. Yogurts were made by addition of LB and ST starter bacteria mixture with the ratio of 1:1 into (A) liquid skim milk, (B) UHT milk, (C) pasteurized milk, (D) UHT milk with the addition of skim powder, (E) pasteurized milk with the addition of skim powder. Fermentation was carried out at $37^{\circ} \mathrm{C}$ for 24 hours.

\section{Analysis Methods}

DPPH Antioxidant Levels. The yogurt was tested for 2,2-diphenyl-1-picrylhidrazyl (DPPH) antioxidant levels. DPPH radical scavenging activity was tested by $3.9 \mathrm{~mL} \mathrm{DPPH}$ solution (DPPH concentration in ethanol 0.004 g. $\mathrm{mL}^{-1}$ ) mixed with $0.1 \mathrm{~mL}$ sample. The mixture was incubated for 30 minutes in a dark room. After that, the samples have recorded the absorbance at a wavelength of $515 \mathrm{~nm}$ (Cirillo 
\& Lemna, 2012). Antioxidant activity was calculated using a standard linear equation with the butylated hydroxytoluene (BHT) as a standard curve.

Color Intensity. BPFE yogurt samples were transferred to a 1-cm path length quartz cell and read for $L, a, b$, values using a CR-400 chroma meter according to method by Zhang et al. (2019). The colored yogurt samples were read in triplicate and compared to each other for color intensity.

\section{Data Analysis}

Data of DPPH antioxidant levels and color were analyzed desctiptively using ANOVA with a significance level of $5 \%$ to determine the effect of differences in the treatment of the addition of blue pea flower extract to yogurt. Analysis continued with Duncan test to see a significant difference. All data are processed using SPSS 16.

\section{RESULT AND DISCUSSION Color Intensity}

The results of the study about the effect of addition of blue pea flower extract on yogurt's color are shown in Table 1 . The brightness or lightness indicated by the $\mathrm{L}^{*}$ value in samples. Based on Table 1, BPFE yogurt from skim milk (37.35) is the lowest compared to yogurt made from other types of milk. The highest $\mathrm{L}^{*}$ value (55.93) showed by BPFE yogurt made from pasteurized milk with skim milk. The red-green level showed as a* value. BPFE yogurt made from UHT milk has the highest $\mathrm{a}^{*}$ value (5.58) means that it showed the reddest intensity. The lowest $a^{*}$ value was BPFE yogurt made from skim milk (2.02) meaningless red intensity. The $b^{*}$ value indicates yellow-blue, with a negative value means blue color. The most significant blue color is BPFE yogurt from UHT milk (-6.72), while the less intensity of $b^{*}$ value showed by BPFE yogurt from pasteurized milk (-0.08).

Blue pea flowers have blue color in the neutral $\mathrm{pH}$ and purple colors when exposed to acid so that it has the potential as an attractive food coloring (Azima et al., 2018; Chu et al., 2016; Rashid et al., 2020; Chusak et al., 2018). The purple color in blue pea flower is known to be anthocyanin, which is one of the antioxidants (Zakaria et al., 2018; Gras, Nemetz, Carle, \& Schweiggert, 2017; Li et al.,
2020). Blue pea flower contain coloring agent with high stability of anthocyanin in the refrigerated condition (Pham et al., 2020). The color degradation and declining effect of anthocyanin-based natural colorant remained constant in refrigerated storage (Anuyahong et al., 2020). The stability of BPFE anthocyanin and their color is mainly influenced by the $\mathrm{pH}$ of the product (Escher et al., 2020b).

Table 1. The $L^{*}, a^{*}, b^{*}$ value of BPFE yogurt

\begin{tabular}{l|c|c|c}
\hline \multirow{2}{*}{ Type of milk } & \multicolumn{3}{|c}{ Color intensity } \\
\cline { 2 - 4 } Skim milk & \multicolumn{1}{|c}{$\mathrm{L}^{*}$} & $\mathrm{a}^{*}$ & $\mathrm{~b}^{*}$ \\
& $1.35 \pm$ & $2.04^{\mathrm{a}} \pm$ & $-1.32 \pm$ \\
& $0.37^{\mathrm{a}}$ & $0.24^{\mathrm{b}}$ \\
Pasteurized & $41.04 \pm$ & $2.51 \pm$ & $-0.08 \pm$ \\
milk & $0.19^{\mathrm{ab}}$ & $0.31^{\mathrm{a}}$ & $0.19^{\mathrm{b}}$ \\
& $42.53 \pm$ & $5.58 \pm$ & $-6.72 \pm$ \\
UHT milk & $1.74^{\mathrm{b}}$ & $0.04^{\mathrm{c}}$ & $0.11^{\mathrm{a}}$ \\
& & & \\
Pasteurized & $55.93 \pm$ & $4.73 \pm$ & $-5.34 \pm$ \\
milk with & $1.29^{\mathrm{c}}$ & $0.11^{\mathrm{b}}$ & $0.69^{\mathrm{a}}$ \\
skim powder & & & \\
UHT milk & $53.73 \pm$ & $4.14 \pm$ & $-2.83 \pm$ \\
with skim & $0.16^{\mathrm{c}}$ & $0.16^{\mathrm{b}}$ & $0.21^{\mathrm{b}}$ \\
powder & & & \\
\hline
\end{tabular}

a-c Different letters represent statistical differences in the color parameter in yogurts with different types of milk $(p<0.05)$

The extract of anthocyanin provided a bright intense purple color to yogurt (Wallace \& Giusti, 2008). The similar result showed in the study of BPFE anthocyanin by Escher et al., (2020b) which exhibit a variation of color between red and green with $\mathrm{pH}$ change from 2.25 to 10.20 . The purple-blue color was clearly showed in $\mathrm{pH}$ range of 3.21-6.14. These findings suggest that BPFE is appropriate for yogurt colorant which is considered as low $\mathrm{pH}$ beverages and stored on refrigerated temperature. The purple color of BPFE yogurt in this study verify a color stability of anthocyanins in acidic medium. The addition of BPFE to yogurt also expected to increase the antioxidant activity of colored yogurt compared to plain yogurt without BPFE.

\section{Antioxidant Activity}

Yogurt is fermented milk that has a sour taste due to a decrease in $\mathrm{pH}$. The decline in $\mathrm{pH}$ occurs along with the formation of lactic acid as a result of the activity of lactic acid bacteria 
(Aryana \& Olson, 2017). The lactic acid bacteria used in this study were Lactobacillus bulgaricus and Streptococcus thermophilus.

Table 2. The $L^{*}, a^{*}, b^{*}$ value of BPFE yogurt

\begin{tabular}{|c|c|c|}
\hline \multirow{2}{*}{ Type of milk } & \multicolumn{2}{|c|}{ DPPH (ppm) } \\
\hline & Plain yogurt & BPFE yogurt \\
\hline Skim milk & $26.33 \pm 1.01^{d}$ & $437.04 \pm 1.52^{\mathrm{d}}$ \\
\hline $\begin{array}{l}\text { Pasteurized } \\
\text { milk }\end{array}$ & $7.03 \pm 0.24^{a}$ & $69.36 \pm 2.68^{a}$ \\
\hline UHT milk & $5.24 \pm 0.12^{\mathrm{a}}$ & $106.33 \pm 5.77^{b}$ \\
\hline $\begin{array}{l}\text { Pasteurized } \\
\text { milk with skim } \\
\text { powder }\end{array}$ & $12.03 \pm 1.39^{b}$ & $91.15 \pm 4.70^{\mathrm{b}}$ \\
\hline $\begin{array}{l}\text { UHT milk with } \\
\text { skim powder }\end{array}$ & $17.04 \pm 1.21^{c}$ & $152.03 \pm 0.21^{c}$ \\
\hline
\end{tabular}

The data on Table 2. showed the influence of BPFE addition to antioxidant activity of yogurt in five different types of milk. Based on Table 2, yogurt from UHT milk has an antioxidant activity of $5.24 \mathrm{ppm}$. After added with the BPFE, antioxidant activity has increased to $106.33 \mathrm{ppm}$. The BPFE yogurt made from UHT milk with skim powder increased to $152.03 \mathrm{ppm}$ compared to the plain yogurt (17.04) of the same types of milk. This trend also occurred in yogurt from pasteurized milk (7.03 ppm) and pasteurized yogurt with skim powder (12.03 $\mathrm{ppm}$ ) compared to the BPFE yogurt made from pasteurized milk (69.36 ppm) and BPFE yogurt from pasteurized milk with skim powder (91.15 ppm). In the yogurt from skimmed milk without the addition of BPFE, the antioxidant activity was $26.33 \mathrm{ppm}$, higher than plain yogurt made from other types of milk. Likewise, with the results of yogurt from skim milk with BPFE addition, antioxidant activity was $437.04 \mathrm{ppm}$ was higher than BPFE yogurt made from other types of milk.

The total antioxidant content of processed milk is mainly due to casein. The differences in UHT treatments, milk composition, melanoidin contents also can be significant influence antioxidant activity of processed milk (Zulueta et al., 2009). The other antioxidants present in milk can be lipid-soluble antioxidant such as carotenoids, retinol, and $\alpha$-tocopherol. Another source of antioxidant is ascorbic acid and Vitamin $\mathrm{E}$ as a water-soluble antioxidant in milk (Khan et al., 2019). These findings explained the DPPH radical scavenging activity in plain yogurt without the addition of BPFE. The dissimilarity in antioxidant activity of all plain yogurt samples might be influenced by diverse content of lipid-soluble antioxidant in each processed milk-based yogurt. Tavakoli, Habibi Najafi, \& Mohebbi (2019) also confirmed that the molecular changes during milk fermentation resulting in different compounds with antioxidant activity such as peptides, free amino acids and fatty acids. The presence of probiotics also proven to enhance the antioxidant activity of yogurts (Donkor, Henriksson, Singh, Vasiljevic, \& Shah, 2007).

Yogurt production with the addition of BPFE increase the antioxidant activity of all samples. Similar studies describe that the antioxidant activity can be improved by incorporating natural extracts into yogurt (Wallace \& Giusti, 2008; Zhang et al., 2019; Anuyahonget al., 2020; Hussein, Awad, ElSayed, \& Ibrahim, 2020) and other food products, such as juices (Lakshan et al., 2019), cakes and bakery (Pasukamonset et al., 2018; Rashid et al., 2020). The addition of natural anthocyanin extract into yogurt has been the subject of many studies. Whole dried seedless Berberisboliviana berries ground rich in anthocyanin addition to yogurt achieved bright, stable, and acceptable color with phenolic stability (Wallace \& Giusti, 2008). Yogurt with Moringa oleifera extract addition exerts positive health benefits and enhanced antioxidant properties (Zhang et al., 2019). Likewise, the addition of riceberry rice (Oryza sativa L.) extract increased the content of anthocyanin and antioxidant activity of yogurt without losing bacterial viability (Anuyahong et al., 2020).

The increased antioxidant activity of BPFE yogurt caused by the anthocyanin pigments, phenolic content, and flavonoids of BPFE. Groups of anthocyanin pigment found in Clitoria ternatea including delphinidin (Azima et al., 2017) and ternatin (Escher et al., 2020b). While the groups of phenolic compounds includes epigallocatechin-3-gallate and kaempferol (Escher et al., 2020b). The flavonoids groups in Clitoria ternatea includes 
quercetin, procyanidin (Escher et al., 2020a), myricetin (Singh et al., 2017), and the other seven types of flavonoid compounds found by Ponnusamy, Gnanaraj, \& Antonisamy (2014).

\section{CONCLUSIONS}

The addition of BPFE can increase antioxidant activity in yogurt made from skim milk, UHT milk, and pasteurized milk, as well as the processed milk added with skim powder. Adding BPFE to yogurt made from UHT milk and pasteurized milk decrease the value of $\mathrm{L}^{*}$, $a^{*}$, and $b^{*}$ (towards purple). Further research Anuyahong,T., Chusak, C., \& Adisakwattana, S.

(2020). Incorporation of anthocyanin-rich riceberry rice in yogurts: Effect on physicochemical properties, antioxidant activity and in vitro gastrointestinal digestion. LWT - Food Science and Technology, 129, 109571. https://doi.org /10.1016/j.lwt.2020.109571.

Aryana, K. J., \& Olson. (2017). A 100-year review: Yogurt and other cultured dairy products. Journal of Dairy Science, 100(12), 9987-10013. https://doi.org/10.3168/jds. 2017-12981.

Azima, A. M. S., Noriham, A., \& Manshoor, N. (2017). Phenolics, antioxidants and color properties of aqueous pigmented plant extracts: Ardisia colorata var. elliptica, Clitoria ternatea, Garcinia mangostana and Syzygium cumini. Journal of Functional Foods, 38, 232-241. https://doi.org/10. 1016/j.jff.2017.09.018.

Chen, C., Zhao, S., Hao, G., Yu, H., Tian, H., \& Zhao, G. (2017). Role of lactic acid bacteria on the yogurt flavour: A review. International Journal of Food Properties, 20(1), S316-S330. https://doi.org/10. 1080/10942912.2017.1295988.

Chu, B.-S., Wilkin, J., House, M., Roleska, M. \& Lemos, M. (2016). Effect of sucrose on thermal and $\mathrm{pH}$ stability of Clitoria ternatea extract. International Journal of Food Processing Technology, 3(1), 11-17. https://doi.org/10.15379/2408-9826.201 6.03.01.02.

Chusak, C., Thilavech, T., Henry, C. J., \& Adisakwattana, S. (2018). Acute effect of Clitoria ternatea flower beverage on glycemic response and antioxidant capacity in healthy subjects: A randomized needs to be done to look at the organoleptic properties of BPFE yogurt.

\section{ACKNOWLEDGEMENT}

This research was funded by Beginner Lecturer Research Grant from Institute of Research and Community Services Universitas PGRI Yogyakarta, Indonesia, number: 301/BAP-LPPM/I/2020.

\section{REFERENCES}

crossover trial. BMC Complementary and Alternative Medicine, 18, 1-11. https://doi. org/10.1186/s12906-017-2075-7

Cirillo, G., \& Lemma, F. (2012). Antioxidant Polymers: Synthesis, Properties, and Applications. New Jersey: Wiley.

Darsini, I. A. P., \& Shamshad, S. (2013). Antimicrobial activity and phytochemical evaluation of Clitoria ternatea. International Journal of Science and Research, 4(5), 2319-7064. https://doi. org/10.1007/BF02930715.JSTOR.

Dhanasekaran, S., Rajesh, A., Mathimani, T., Samuel, S. M., Shanmuganathan, R., \& Brindhadevi, K. (2019). Efficacy of crude extracts of Clitoria ternatea for antibacterial activity against gram negative bacterium (Proteus mirabilis). Biocatalysis and Agricultural Biotechnology, 21, 101328. https://doi.org/10.1016/j.bcab.2019.1013 28.

Donkor, O. N., Henriksson, A., Singh, T. K., Vasiljevic, T., \& Shah, N. P. (2007). ACEinhibitory activity of probiotic yoghurt. International Dairy Journal, 17(11), 13211331. https://doi.org/10.1016/j.idairyj.20 07.02.009.

Escher, G. B., Marques, M. B., do Carmo, M., Azevedo, L., Furtado, M. M., Sant'Ana, A. S., ... Granato, D. (2020a). Clitoria ternatea L. petal bioactive compounds display antioxidant, antihemolytic and antihypertensive effects, inhibit $\alpha$-amylase and $\alpha$-glucosidase activities and reduce human LDL cholesterol and DNA induced oxidation. Food Research International, 128, 108763. https://doi.org/10.1016/j.foodres .2019.108763. 
Escher, G. B., Wen, M., Zhang, L., Rosso, N. D., \& Granato, D. (2020b). Phenolic composition by UHPLC-Q-TOF-MS/MS and stability of anthocyanins from Clitoria ternatea L. (butterfly pea) blue petals Graziela. Food Chemistry, 331, 127341. https://doi.org/10.1016/j.foodchem.2020. 127341.

Ezzudin, R. M., \& Rabeta, M. S. (2018). A potential of telang tree (Clitoria ternatea) in human health. Food Research, 2(5), 415420. doi: 10.26656/fr.2017.2(5).073.

Gras, C. C., Nemetz, N., Carle, R., \& Schweiggert, R. M. (2017). Anthocyanins from purple sweet potato (Ipomoea batatas (L.) Lam.) and their color modulation by the addition of phenolic acids and foodgrade phenolic plant extracts. Food Chemistry, 235, 265-274. https://doi.org/ 10.1016/j.foodchem.2017.04.169.

Hussein, H., Awad, S., El-Sayed, I., \& Ibrahim, A. (2020). Impact of chickpea as prebiotic, antioxidant and thickener agent of stirred bio-yoghurt. Annals of Agricultural Sciences, 65(1), 49-58. https://doi.org/10.1016/ j.aoas.2020.03.001.

Khan, I. M., Bule, M., Ullah, R., Nadeem, M., Asif, S., \& Niaz, K. (2019). The antioxidant components of milk and their role in processing, ripening, and storage: Functional food. Veterinary World, 12(1), 12-33. https://doi.org/10.14202/vetworld .2019.12-33

Lakshan, S. A. T., Jayanath, N. Y., Abeysekera,W. P. K. M., \& Abeysekera,W. K. S. M. (2019). A commercial potential blue pea (Clitoria ternatea L.) flower extract incorporated beverage having functional properties. Evidence-Based Complementary and Alternative Medicine, 2019, 2916914. https://doi.org/10.1155/2019/2916914.

Li, X., Zhang, L., Peng, Z., Zhao, Y., Wu, K., Zhou, N., ... Bai, W. (2020). The impact of ultrasonic treatment on blueberry wine anthocyanin color and its In-vitro anti-oxidant capacity. Food Chemistry, 333, 127455. https://doi.org/10.1016/j. foodchem.2020.127455.

McFarland, L. V. (2015). From yaks to yogurt: The history, development, and current use of probiotics. Clinical Infectious Diseases, 60(2), S85-S90. https://doi.org/10.1093/ $\mathrm{cid} / \mathrm{civ} 054$.
Nagaoka, S. (2018). Yogurt Production. In M. Kanauchi (Ed.), Methods in Molecular Biology (pp. 45-54). New York: Humana Press. doi: 10.1007/978-1-4939-8907-2_5.

Pasukamonset, P., Pumalee, T., Sanguansuk, N., Chumyen, C., Wongvasu, P., Adisakwattana, S., \& Ngamukote, S. (2018). Physicochemical, antioxidant and sensory characteristics of sponge cakes fortified with Clitoria ternatea extract. Journal of Food Science and Technology, 55, 2881-2889. https://doi.org/10.1007/s131 97-018-3204-0.

Pham, T. N., Le, X. T., Nguyen, P. T. N., Tran, T. H., Dao, T. P., Nguyen, D. H., ... Anh, H. L. T. (2020). Effects of storage conditions on total anthocyanin content of butterfly pea flower (Clitoria ternatea L.). IOP Conf. Ser.: Mater. Sci. Eng., 736, 062005. https://doi.org/10.1088/1757-899X/736/ 6/062005.

Ponnusamy, S., Gnanaraj, W. E., \& Antonisamy, J. M. (2014). Flavonoid profile of Clitoria ternatea Linn. Traditional Medicine Journal, 19(1), 1-5. https://doi.org/10.22146/tradmedj.8083.

Rashid, S. A., Tong, W. Y., Leong, C. R., Ghazali, N.M. A., Taher, M. A., Ahmad, N., ... Teo, S. H. (2020). Anthocyanin microcapsule from Clitoria ternatea: potential biopreservative and blue colorant for baked food products. Arabian Journal for Science and Engineering, 46, 65-72. https://doi. org/10.1007/s13369-020-04716-y.

Sieuwerts, S., de Bok, F. A. M., Hugenholtz, J., \& van Hylckama Vlieg, J. E. T. (2008). Unraveling microbial interactions in food fermentations: From classical to genomics approaches. Applied and Environmental Microbiology, 74(16), 4997-5007. https:// doi.org/10.1128/AEM.00113-08.

Singh, N. K., Gupta, J. K., Shah, K., Mishra, P., Tripathi, A., Chauhan, N. S., \& Upmanyu, N. (2017) A Review on Clitoria ternatea (Linn.): Chemistry and Pharmacology. In b. Kshetrimayum (Ed.), Medicinal Plants and Its Therapeutic Uses. Hyderabad: OMICS International. https://doi.org/10.4172/97 8-1-63278-074-4-075.

Spence, C. (2019). On the changing colour of food \& drink. International Journal of Gastronomy and Food Science, 17, 100161. 
https://doi.org/10.1016/j.ijgfs.2019.1001 61.

Tavakoli, M., Habibi Najafi, M. B., \& Mohebbi, M. (2019). Effect of the milk fat content and starter culture selection on proteolysis and antioxidant activity of probiotic yogurt. Heliyon, 5(2), e01204. doi:10.1016/j.heliyon.2019.e01204.

Wallace, T. C., and Giusti, M. M. (2008). Determination of color, pigment, and phenolic stability in yogurt systems colored with nonacylated anthocyanins from Berberis boliviana L. as compared to other natural/synthetic colorants. Journal of Food Science, 73(4), C241-C248. https://doi.org /10.1111/j.1750-3841.2008.00706.x.

Yıldız, N., \& Bakirci, I. (2019). Investigation of the use of whey powder and buttermilk powder instead of skim milk powder in yogurt production. Journal of Food Science and Technology, 56(10), 4429-4436. https://doi.org/10.1007/s13197-019-039 53-w.

Zakaria, N., Okello, E. J., Howes, M. J., BirchMachin, M. A., \& Bowman, A. (2018). In vitro protective effects of an aqueous extract of Clitoria ternatea L. flower against hydrogen peroxide-induced cytotoxicity and UV-induced mtDNA damage in human keratinocytes. Phytotherapy Research, 32(6), 1064-1072. https://doi.org/10.100 2/ptr.6045.

Zhang, T., Jeong, C. H., Cheng, W. N., Bae, H., Seo, H. G., Petriello, M. C., Han, S. G. (2019). Moringa extract enhances the fermentative, textural, and bioactive properties of yogurt. LWT - Food Science and Technology, 101, 276-284. https://doi.org/10.1016/j.lwt.2018.11.01 0 .

Zingare, M. L., Zingare, P. L., Dubey, A., \& Ansari, A. (2013). Clitoria ternatea (Aparajita): A review of the antioxidant, antidiabetic and hepatoprotective potentials. International Journal of Pharmacy and Biological Sciences, 3(1), 203213.

Zulueta, A., Maurizi, A., Frigola, A., Esteve, M. J., Coli, R., \& Burini, G. (2009). Antioxidant capacity of cow milk, whey and deproteinized milk. International Dairy Journal, 19, 380-385. https://doi.org/10. 1016/j.idairyj.2009.02.003. 